조사료원과 출하시기가 거세한우의 발육과 도체특성에 미치는 영향 조원모 · 장선식 · 조영무 · 김형철 · 권응기 · 양승학 · 백봉현

\title{
Effects of Forage Source and Shipping Time on Growth Performance and Carcass Characteristics of Hanwoo Steers
}

Won-Mo Cho, Sun-Sik Chang, Young-Moo Cho, Hyeong-Cheol Kim, Eung-Gi Kwon, Seung Hak Yang and Bong-Hyun Paek

\begin{abstract}
This study examined the influence of forage source (grass hay and rice straw) and shipping time (24, 26, 28 and 30 months) on feed conversion ratio, growth performance and carcass characteristics of Hanwoo steers. Sixty four Hanwoo steers at 6 months age were fed either grass hay $(n=32)$ or rice straw $(n=32)$ for 24, 26, 28 and 30 months of age. Steers fed on mixed grass hay gained significantly higher body weight at 24, 26, 28 and 30 months compared with those fed on rice straw. Feed efficiency was slightly better in steers fed mixed grass hay compared to those fed rice straw. Back fat thickness and marbling score were increased with the age of steers $(\mathrm{p}<0.05)$. Carcass quality traits (meat color, fat color, texture and maturity) were not affected by forage source and shipping time. Shear force, cooking loss and water holding capacity of beef were reduced with advancing age of steers $(\mathrm{p}<0.05)$. Moisture content was lower and fat content was higher in beef produced from steers fed mixed grass hay than those fed rice straw $(\mathrm{p}<0.05)$. Beef juiciness was reduced with the advancing shipping time of steers. In conclusion, it would be beneficial to feed hay compared with rice straw during whole period of Hanwoo steer to produce high quality beef.
\end{abstract}

(Key words : Hanwoo steer, Forage, Growth performance, Carcass characteristics, Fattening period)

I. 서 론

한우사육농가들의 고급육 생산에 관심 ('08. 거세한우 육질1등급 출현율 $75.6 \%$ )이 높아지면 서 거세 및 장기비육이 선호되고 있어, 이에 따른 양질조사료 급여가 중요시 되고 있다. 일 반적으로 한우사육농가에서는 조사료원으로 볏 짚을 이용하고 있으나 고급육 생산에는 한계가 있으므로 목건초 등 양질조사료 급여와 비육기 간을 연장하여 고급육을 생산하는 농가도 최근
에는 증가하는 추세이다. 농후사료 위주의 사 양관리는 산독증과 같은 대사성 질병을 유발시 킬 우려가 크고, 반추동물인 소에게는 산육 생 리적으로 적정량의 조사료 급여가 필요하며 (백 등, 1987; 홍 등, 1992), 또한 한우고급육 생산 은 조사료원 (목건초 및 볏짚)의 차이에 따라 비육성적과 도체특성이 달라진다 (백 등, 1992). 한우농가에서 주로 이용하고 있는 볏짚은 사료 가치가 낮게 평가되고 있는데, 이는 세포벽에 함유된 silica 함량이 높은 것으로부터 유래되

국립축산과학원 (National Institute of Animal Science, RDA, Cheonan, 330-801, Korea)

Corresponding author: W. M. Cho, National Institute of Animal Science, RDA, Cheonan, 330-801, Korea. Tel : +82-41-580-3383. Fax: +82-41-580-3419, E-mail : cwmo3451@korea.kr 
고 있으며 (Van Soest, 1982), 이를 개선하기 위 해서 여러 가지 방법 등이 제시되고 있는데 그 중 하나로 암모니아를 처리하면 조단백질 함량 이 2 3배 증가된다고 하였다(Horton 등, 1978). 또한 양질조사료 급여시 증체량 및 사료 효율이 개선되었다는 보고도 있다(강, 1979; White 등, 1969). 육성기는 방목위주로, 비육기 에는 양질조사료 급여로 육질이 개선 (skelley 등, 1978)된다고 하였다. 한편 홍 등 (1994)은 볏짚과 담근먹이를 자유채식 시키면서 배합사 료를 육성기에 체중의 $1.5 \%$ 내외로 제한급여 하였을 때 옥수수담근먹이가 가장 발육이 향상 되었으며, 볏짚이용구가 가장 낮았다고 보고하 였다. 총 섭취사료 중 조섬유 함량이 적정량에 못 미칠 경우 반추위내 산도가 저하되어 대사 성 질병을 유발할 수 있다고 하였다(백 등, 1991). 이와 같이 농후사료뿐만 아니라 조사료 의 종류에 따라서도 비육에 있어서 많은 변동 을 가져 올 수 있다는 결과들로부터 반추위 생 리에 적합한 환경을 만들면서 조사료원별 장기 비육에 따른 증체효과 및 사료섭취량을 알아보
고자 본 시험을 실시하였다.

\section{ㅍ. 재료 및 방법}

1. 공시축

본 시험은 축산과학원 한우시험장 (강원도 평 창군 소재)에서 생후 6개월령 거세한우 64두 (평균 체중: 목건초구 $156.0 \mathrm{~kg}$, 볏짚구 149.7 $\mathrm{kg}$ )를 총 24 개월간 공시하였다.

\section{2. 시험설계 및 시험사료}

6개월령인 거세한우를 64 두를 주구는 조사료 원으로 목건초와 볏짚 처리구를 배치하였으며, 세구는 출하시기로 24 개월령, 26개월령, 28개월 령 및 30개월령 배치하였다. 2000년 2월부터 2002년 1월까지 총 24개월간 본 사양시험을 실 시하였다. 농후사료는 시판 비육사료 (Table 1 및 Table 2)를 이용하였다. 조사료로는 국립축 산과학원 한우시험장에서 수확한 오차드그라스

Table 1. Ingredient composition of experimental diets (\%, as fed basis)

\begin{tabular}{|c|c|c|c|}
\hline Ingredients & Growing stage ${ }^{1)}$ & Fattening stage $\mathrm{I}^{2)}$ & Fattening stage $\Pi^{3)}$ \\
\hline Corn, ground & 41.0 & 47.8 & 56.0 \\
\hline Wheat bran & 40.6 & 41.0 & 36.9 \\
\hline Soybean meal & 6.0 & 5.0 & 3.0 \\
\hline Canola meal & 8.0 & 2.0 & - \\
\hline Molasses & 2.0 & 2.0 & 2.0 \\
\hline Limestone & 1.7 & 1.5 & 1.1 \\
\hline Salt & 0.4 & 0.4 & 0.4 \\
\hline Calcium phosphate & - & - & 0.3 \\
\hline Mineral mixture ${ }^{4)}$ & 0.2 & 0.2 & 0.2 \\
\hline ACID-LAC & 0.1 & 0.1 & 0.1 \\
\hline Total & 100 & 100 & 100 \\
\hline
\end{tabular}


Cho et al.: The Growth Performance and Meat Quality by Forage Source on Hanwoo Steers

Table 2. Chemical composition of experimental diets (\%, as fed basis)

\begin{tabular}{lcccccccc}
\hline Diets & Mois. & CP & EE & CF & NFE & NDF & ADF & TDN \\
\hline \hline $\begin{array}{l}\text { Concentrates } \\
\quad \text { - Growing stage }\end{array}$ & 12.59 & 13.81 & 3.09 & 5.61 & 58.72 & - & - & 70.2 \\
$\quad$ - Fattening stage I & 13.54 & 12.45 & 2.52 & 4.30 & 60.99 & - & - & 71.2 \\
$\quad$ - Fattening stage $\square$ & 13.36 & 11.99 & 2.37 & 4.61 & 62.47 & - & - & 72.3 \\
\hline Roughages & & & & & & & & \\
$\quad$ - Hay & 12.31 & 9.12 & 0.94 & 33.31 & 44.32 & 62.52 & 40.61 & 55.44 \\
$\quad$ - Rice straw & 15.80 & 4.78 & 1.14 & 29.61 & 48.67 & 63.56 & 42.40 & 38.29 \\
\hline
\end{tabular}

Abbreviations : Mois.: moisture, CP: crude protein, EE : ether extract, NFE: nitrogen-free extracts, NDF : neutral detergent fiber, ADF : acid detergent fiber, TDN : total digestible nutrients(calculated value).

위주의 건초를 이용하였으며, 볏짚은 시중에서 유통되는 세절볏짚을 구입 이용하였다. 성장단 계별 급여 농후사료와 조사료의 영양소 함량은 Table 2와 같다.

\section{3. 사양관리}

시험축은 개방식 우사에서 pen 당 8 두씩 군 사시켰으며, 사육기간은 육성기 $(6 \sim 12$ 개월령까 지), 비육전기 (13 18개월령) 및 비육후기 (19 $\sim 24,26,28$ 및 30 개월령) 3 단계로 나누어 사 육하였다. 시험기간 동안 배합사료는 각 성장 단계별로 체중의 $1.5 \%$ 로 제한급여 하였으며, 조사료는 볏짚 및 목건초 모두 육성기에는 자 유채식, 비육전기는 체중의 $1.0 \%$, 비육후기는 $0.8 \%$ 로 제한급여 하였다. 신선한 물은 항상 섭 취가 가능하도록 하였으며, 미네랄 보충을 위 해서 미네랄블록을 전기간 자유롭게 섭취하도 록 하였다.

\section{4. 조사항목 및 방법}

체중은 시험 개시부터 1 개월 간격으로 오전 사료 급여 전에 측정하였으며, 사료섭취량은 매일 아침 9시 사료를 급여하기 전, 전일에 급 여한 사료의 잔량을 측정하는 방법으로 조사하
였다. 시험사료의 일반성분은 $\mathrm{AOAC}$ 법 (1990)에 준하여, $\mathrm{ADF}$ (acid detergent fiber) 및 $\mathrm{NDF}$ (neutral detergent fiber)는 Van Soest 방법 (1982) 에 의하여 분석하였다. 출하축은 사양시험 종 료 후 24시간 절식시켜 국립축산과학원 내 도 축장으로 운송 즉시 체중측정 후 도축하였다. 도축 후 $5^{\circ} \mathrm{C}$ 내외에서 1 일간 냉각하였으며, 도 체등급 판정은 한국 소 도체등급판정기준 (축산 물등급판정소, 2001)에 준하여 축산물등급판정 사가 평가하였다.

\section{5. 통계분석}

본시험의 모든 성적은 SAS (Statistical Analysis System) package (Cary, NC., 1997)를 이용하여 통계분석 하였으며, 처리간 유의성 $(\mathrm{p}<0.05)$ 은 Duncan's multiple range test 방법을 이용하여 검정하였다.

\section{피. 결과 및 고찰}

\section{1. 발육능력}

조사료원 (볏짚 및 목건초)별 출하월령에 따 른 발육능력 및 사료섭취량을 구명하기 위하여 6 개월령부터 24 개월령까지 비육하고 그 이후부 
터 2 개월 간격으로 30 개월령까지 발육을 조사 한 결과 목건초 급여구가 볏짚 급여구에 비하 여 동일 출하월령에서 $10 \sim 12 \%$ 정도 더 발육이 향상되었다 $(\mathrm{p}<0.05)$. 또한 볏짚급여구가 목건초 급여구에 비하여 출하시기별 일당증체량은 낮 았다 $(\mathrm{p}<0.05)$. 이것은 양질조사료급여에 의한 효과로 판단된다. 반추가축의 성장에 있어 육 성기에는 에너지와 단백질 등의 영양소섭취량 이 증체에 크게 영향을 미치고 비육기의 증체 는 주로 에너지의 섭취량에 의해 결정된다고 하였다 (Martin 등, 1978). 따라서 본 시험은 육 성기의 반추위발달로 인한 비육기의 사료이용 효율의 향상으로 발육이 증가한 것으로 사료되 며, 전체적으로 발육이 저조한 것은 전 기간 제한사양으로 인한 충분한 발육이 이루어지지 못한 것으로 생각이 된다. 또한 Butterfield와 May (1966) 및 Berge (1991)는 저 영양으로 인 하여 지연된 성장이 그 이후의 영양 상태에 따 라 급격히 회복될 수 있지만 그 보상급여기간 이 충분히 길지 않을 경우 정상적인 영양수준 으로 급여한 소의 증체율에 미치지 못한다고 보고하였다.

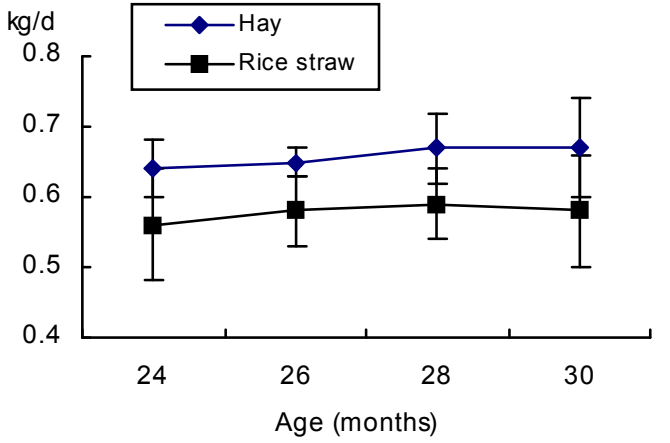

Fig. 1. The change of daily gains in Hanwoo steers fed either hay or rice straw for different shipping stages.

\section{2. 사료이용효율}

본 시험에서는 목건초급여구의 $\mathrm{kg}$ 증체당 배 합사료 요구량에서도 24 개월령의 경우 $7.0 \mathrm{~kg}$ 이 였으나, 30 개월령의 경우는 $8.4 \mathrm{~kg}$ 으로 출하시 기가 늦을수록 요구량도 증가하였다. 볏짚급여 구의 경우도 $\mathrm{kg}$ 증체당 배합사료 요구량에서도 24 개월령 $7.2 \mathrm{~kg}$, 30개월령 $8.8 \mathrm{~kg}$ 으로 출하시기 가 늦을수록 요구량도 증가하였다. 볏짚급여구 가 목건초 급여구에 비하여 $\mathrm{kg}$ 증체당 배합사

Table 3. Body weight change of Hanwoo steers fed either hay or rice straw for different shipping stages

\begin{tabular}{|c|c|c|c|}
\hline Items (months) & Initial body weight & Final body weight & Total weight gain \\
\hline Hay & $156.0 \pm 5.4$ & & \\
\hline-24 & & $506.2^{\mathrm{a}} \pm 9.9$ & $350.2 \pm 6.4$ \\
\hline-26 & & $552.9^{\mathrm{a}} \pm 13.0$ & $396.9 \pm 9.2$ \\
\hline-28 & & $605.9^{\mathrm{a}} \pm 15.2$ & $449.9 \pm 11.3$ \\
\hline-30 & & $645.1^{\mathrm{a}} \pm 18.8$ & $489.1 \pm 12.5$ \\
\hline Rice straw & $149.7 \pm 3.2$ & & \\
\hline-24 & & $458.9^{\mathrm{b}} \pm 11.5$ & $309.2 \pm 7.3$ \\
\hline-26 & & $502.8^{\mathrm{b}} \pm 16.1$ & $353.1 \pm 13.4$ \\
\hline-28 & & $542.9^{\mathrm{b}} \pm 16.3$ & $393.2 \pm 14.6$ \\
\hline-30 & & $571.8^{\mathrm{b}} \pm 20.9$ & $422.1 \pm 15.1$ \\
\hline
\end{tabular}

${ }^{a, b}$ Means with different superscripts in the same row are significantly different $(p<0.05)$. 
Table 4. Feed conversion ratio in Hanwoo steers fed either hay or rice straw for different shipping stages

\begin{tabular}{lccc}
\hline \multirow{2}{*}{ Items (months) } & \multicolumn{3}{c}{ Feed requirement $(\mathrm{DM}, \mathrm{kg} / \mathrm{kg}$ gain) } \\
\cline { 2 - 4 } Hay & & Forage & Total \\
$\quad-24$ & $7.0 \pm 0.3$ & & $13.0 \pm 0.3$ \\
-26 & $7.4 \pm 0.5$ & $6.0 \pm 0.2$ & $13.3 \pm 0.4$ \\
-28 & $7.8 \pm 0.2$ & $5.9 \pm 0.4$ & $13.5 \pm 0.3$ \\
-30 & $8.4 \pm 0.7$ & $5.7 \pm 0.3$ & $14.1 \pm 0.5$ \\
\hline \hline Rice straw & & $5.7 \pm 0.3$ & \\
-24 & $7.2 \pm 0.6$ & & $12.5 \pm 0.3$ \\
-26 & $7.6 \pm 0.7$ & $5.3 \pm 0.1$ & $12.9 \pm 0.4$ \\
-28 & $8.0 \pm 0.3$ & $5.3 \pm 0.4$ & $13.2 \pm 0.3$ \\
-30 & $8.8 \pm 0.5$ & $5.2 \pm 0.3$ & $14.1 \pm 0.4$ \\
\hline
\end{tabular}

Means with different superscripts in the same row are not significantly different $(\mathrm{p}<0.05)$.

Table 5. Carcass characteristics in Hanwoo steers fed either hay or rice straw for different shipping stages

\begin{tabular}{|c|c|c|c|c|c|c|c|c|}
\hline \multirow{2}{*}{ Items } & \multicolumn{2}{|c|}{24 months } & \multicolumn{2}{|c|}{26} & \multicolumn{2}{|c|}{28} & \multicolumn{2}{|c|}{30} \\
\hline & Hay & $\mathrm{RS}^{1)}$ & Hay & RS & Hay & RS & Hay & $\mathrm{RS}$ \\
\hline \multicolumn{9}{|l|}{ Yield traits } \\
\hline \multirow[t]{2}{*}{ Back fat thickness (mm) } & $5.8^{\mathrm{b}}$ & $4.0^{\mathrm{b}}$ & $5.9^{\mathrm{b}}$ & $4.1^{b}$ & $7.0^{\mathrm{ab}}$ & $6.1^{\mathrm{ab}}$ & $10.1^{\mathrm{a}}$ & $6.8^{\mathrm{a}}$ \\
\hline & \pm 2.1 & \pm 3.2 & \pm 2.5 & \pm 2.8 & \pm 4.7 & \pm 2.3 & \pm 4.8 & \pm 2.9 \\
\hline \multirow[t]{2}{*}{ Rib eye area $\left(\mathrm{cm}^{2}\right)$} & $73.5^{\mathrm{b}}$ & $67.8^{\mathrm{b}}$ & $74.9^{\mathrm{b}}$ & $75.3^{\mathrm{ab}}$ & $81.7^{\mathrm{ab}}$ & $80.0^{\mathrm{a}}$ & $84.1^{\mathrm{a}}$ & $76.6^{\mathrm{ab}}$ \\
\hline & \pm 7.5 & \pm 8.9 & \pm 9.8 & \pm 8.5 & \pm 10.5 & \pm 11.2 & \pm 8.7 & \pm 11.2 \\
\hline \multirow[t]{2}{*}{ Cold carcass wt. (kg) } & $292.1^{b}$ & $251.1^{\mathrm{c}}$ & $321.6^{\mathrm{b}}$ & $279.4^{\mathrm{cb}}$ & $369.3^{\mathrm{a}}$ & $323.8^{\mathrm{ab}}$ & $391.8^{\mathrm{a}}$ & $337.3^{\mathrm{a}}$ \\
\hline & \pm 30.1 & \pm 28.5 & \pm 33.1 & \pm 28.3 & \pm 33.2 & \pm 30.5 & \pm 35.2 & \pm 29.7 \\
\hline Grade (A:B:C) & $7: 1: 0$ & $1: 7: 0$ & $4: 3: 0$ & $4: 3: 0$ & $4: 3: 0$ & $5: 3: 0$ & $4: 2: 1$ & $6: 2: 0$ \\
\hline \multicolumn{9}{|l|}{ Quality traits } \\
\hline Marbling score ${ }^{2)}$ & $2.0^{\mathrm{a}} \pm 0.9$ & $1.3^{\mathrm{b}} \pm 1.1$ & $2.7^{\mathrm{ab}} \pm 0.9$ & $1.3 \pm 0.8^{\mathrm{a}}$ & $3.4^{\mathrm{ab}} \pm 1.1$ & $1.6^{\mathrm{a}} \pm 1.3$ & $4.1^{\mathrm{b}} \pm 0.8$ & $3.3^{\mathrm{b}} \pm 0.9$ \\
\hline Meat color ${ }^{3)}$ & $4.9 \pm 0.2$ & $5.1 \pm 0.3$ & $4.3 \pm 0.1$ & $4.6 \pm 0.2$ & $4.4 \pm 0.1$ & $3.6 \pm 0.1$ & $4.9 \pm 0.2$ & $4.8 \pm 0.2$ \\
\hline Fat color ${ }^{4)}$ & $2.8 \pm 0.1$ & $2.6 \pm 0.2$ & $2.7 \pm 0.0$ & $2.7 \pm 0.0$ & $2.7 \pm 0.0$ & $2.8 \pm 0.1$ & $2.9 \pm 0.0$ & $2.8 \pm 0.0$ \\
\hline Texture $^{5)}$ & $1.9 \pm 0.3$ & $2.0 \pm 0.1$ & $1.9 \pm 0.4$ & $2.0 \pm 0.0$ & $1.6 \pm 0.1$ & $1.8 \pm 0.3$ & $1.4 \pm 0.5$ & $1.8 \pm 0.2$ \\
\hline Maturity $^{6}$ & $1.0 \pm 0.0$ & $1.0 \pm 0.0$ & $1.0 \pm 0.0$ & $1.0 \pm 0.0$ & $1.0 \pm 0.0$ & $1.0 \pm 0.0$ & $2.0 \pm 0.0$ & $2.0 \pm 0.0$ \\
\hline Grade $\left(1^{+}: 1: 2: 3\right)^{7)}$ & $0: 1: 5: 2$ & $0: 0: 1: 7$ & $0: 2: 3: 2$ & $0: 0: 1: 6$ & $1: 2: 3: 1$ & $0: 1: 2: 5$ & $1: 4: 2: 0$ & $0: 3: 5: 0$ \\
\hline
\end{tabular}


Table 6. Carcass physical and chemical characteristics of Hanwoo steers fed either hay or rice straw (RS) for different shipping stages

\begin{tabular}{|c|c|c|c|c|c|c|c|c|}
\hline \multirow{2}{*}{ Items } & \multicolumn{2}{|c|}{24 month } & \multicolumn{2}{|c|}{26} & \multicolumn{2}{|c|}{28} & \multicolumn{2}{|c|}{30} \\
\hline & Hay & RS & Hay & $\mathrm{RS}$ & Hay & $\mathrm{RS}$ & Hay & $\mathrm{RS}$ \\
\hline \multirow{2}{*}{$\begin{array}{l}\text { Shear force } \\
\qquad\left(\mathrm{kg} / \mathrm{cm}^{2}\right)\end{array}$} & $4.2^{\mathrm{a}}$ & $6.7^{\mathrm{a}}$ & $4.3^{\mathrm{a}}$ & $4.3^{\mathrm{b}}$ & $3.4^{\mathrm{b}}$ & $3.9^{\mathrm{b}}$ & $3.5^{\mathrm{b}}$ & $3.8^{\mathrm{b}}$ \\
\hline & \pm 1.2 & \pm 0.8 & \pm 1.1 & \pm 1.2 & \pm 0.9 & \pm 0.8 & \pm 0.7 & \pm 0.8 \\
\hline \multirow[t]{2}{*}{ Cooking loss $(\%)$} & $28.3^{\mathrm{a}}$ & $30.8^{\mathrm{a}}$ & $26.4^{\mathrm{a}}$ & $26.6^{\mathrm{b}}$ & $27.9^{\mathrm{a}}$ & $30.3^{\mathrm{a}}$ & $23.7^{\mathrm{b}}$ & $24.9^{\mathrm{b}}$ \\
\hline & \pm 2.5 & \pm 2.1 & \pm 2.2 & \pm 2.5 & \pm 1.9 & \pm 2.0 & \pm 3.1 & \pm 2.1 \\
\hline \multirow{2}{*}{$\begin{array}{l}\text { Water holding } \\
\text { capacity }(\%)\end{array}$} & $56.3^{\mathrm{a}}$ & $53.0^{\mathrm{a}}$ & $53.4^{\mathrm{ab}}$ & $52.9^{\mathrm{a}}$ & $51.4^{\mathrm{b}}$ & $51.4^{\mathrm{ab}}$ & $47.6^{c}$ & $48.5^{\mathrm{b}}$ \\
\hline & \pm 3.6 & \pm 2.8 & \pm 4.1 & \pm 2.1 & \pm 3.0 & \pm 2.1 & \pm 2.8 & \pm 3.1 \\
\hline \multirow{2}{*}{ Moisture (\%) } & $71.8^{\mathrm{a}}$ & $73.7^{\mathrm{a}}$ & $70.3^{\mathrm{ab}}$ & $72.4^{\mathrm{a}}$ & $69.2^{\mathrm{bc}}$ & $72.0^{\mathrm{ab}}$ & $67.4^{\mathrm{c}}$ & $69.8^{\mathrm{b}}$ \\
\hline & \pm 3.5 & \pm 3.8 & \pm 3.1 & \pm 2.5 & \pm 2.9 & \pm 3.7 & \pm 2.3 & \pm 2.1 \\
\hline \multirow{2}{*}{ Ether extract (\%) } & $5.2^{\mathrm{c}}$ & $3.1^{\mathrm{b}}$ & $6.5^{\mathrm{bc}}$ & $4.0^{\mathrm{b}}$ & $8.4^{\mathrm{ab}}$ & $4.8^{\mathrm{b}}$ & $10.8^{\mathrm{a}}$ & $7.9^{\mathrm{a}}$ \\
\hline & \pm 0.8 & \pm 1.2 & \pm 0.9 & \pm 0.5 & \pm 1.1 & \pm 0.7 & \pm 0.9 & \pm 0.8 \\
\hline \multirow{2}{*}{ СР (\%) } & $21.8^{\mathrm{a}}$ & $21.7^{\mathrm{a}}$ & $20.9^{\mathrm{b}}$ & $21.2^{\mathrm{ab}}$ & $20.8^{\mathrm{b}}$ & $21.4 \mathrm{a}$ & $20.1^{\mathrm{b}}$ & $20.6^{\mathrm{b}}$ \\
\hline & \pm 2.1 & \pm 1.8 & \pm 1.5 & \pm 1.1 & \pm 1.8 & \pm 1.4 & \pm 0.9 & \pm 0.8 \\
\hline \multirow[t]{2}{*}{ Juiceness ${ }^{1)}$} & $4.9^{\mathrm{a}}$ & $4.8^{\mathrm{a}}$ & $4.2^{\mathrm{b}}$ & $4.5^{\mathrm{ab}}$ & $4.3^{\mathrm{b}}$ & $3.8^{\mathrm{b}}$ & $4.4^{\mathrm{b}}$ & $4.3^{\mathrm{ab}}$ \\
\hline & \pm 0.4 & \pm 0.2 & \pm 0.6 & \pm 0.2 & \pm 0.3 & \pm 0.3 & \pm 0.4 & \pm 0.2 \\
\hline \multirow[t]{2}{*}{ Tenderness $^{2)}$} & 4.6 & 4.0 & 3.8 & 4.0 & 4.5 & 3.9 & 3.9 & 4.2 \\
\hline & \pm 0.5 & \pm 0.2 & \pm 0.3 & \pm 0.1 & \pm 0.2 & \pm 0.3 & \pm 0.2 & \pm 0.2 \\
\hline \multirow[t]{2}{*}{ Flavor $^{3)}$} & $5.0^{\mathrm{a}}$ & $4.8^{\mathrm{a}}$ & $4.5^{\mathrm{b}}$ & $4.5^{\mathrm{ab}}$ & $4.5^{\mathrm{b}}$ & $4.3^{\mathrm{b}}$ & $4.8^{\mathrm{ab}}$ & $4.4^{\mathrm{ab}}$ \\
\hline & \pm 0.5 & \pm 0.4 & \pm 0.5 & \pm 0.1 & \pm 0.4 & \pm 0.3 & \pm 0.4 & \pm 0.2 \\
\hline
\end{tabular}

1),2),3) : panel test score : 1=very bad) to $5=$ very good.

${ }^{a, b, c}$ Means with different superscripts in the same row are significantly different $(\mathrm{p}<0.05)$.

료 요구량은 약간 증가하는 경향을 보였다. O'Donovan(1984)는 소를 조기에 제한사양 할 경우 그 이후의 영양상태에 따라 보상성장의 효과가 증가되었다고 하였으며, Saubidet 등 (1976)은 제한 사양이 끝난 후 보상성장 기간 초기에만 일시적으로 사료섭취량 증가와 발육 이 향상되었다고 하였다. 이와는 달리 Abdalla 등 (1988)는 제한사양이후 장기간 사료섭취량 증가가 계속되었다고 하였다. 백 등 (1992)이 보고한 24개월령 $550 \mathrm{~kg}$ 출하시 $1 \mathrm{~kg}$ 증체당 농 후사료소요량이 $7.0 \mathrm{~kg}$ 으로 유사한 성적을 얻었 다. White 등 (1969)은 볏짚 이용구보다 목건초
이용구에서 배합사료 이용효율이 향상되었다고 보고한 내용과도 동일한 결과를 얻었다.

\section{3. 도체특성}

도체특성을 살펴보면 목건초 급여구 및 볏짚 급여구 모두 출하월령이 증가할수록 육량등급 에서 중요한 요인인 등지방 두께가 증가 $(\mathrm{p}<0.05)$ 하였다. 배최장근 단면적에서는 목건초 급여구에서 출하월령이 늘어날수록 증가하였으 나, 볏짚의 경우는 30 개월령에서 28 개월령보다 낮아지는 경향을 보였다. 육질등급에 있어서는 
목건초의 경우 출하월령이 증가할수록 근내지 방도의 향상이 분명하였으나, 볏짚의 경우는 증가폭이 낮았다. 이것은 비육전기 동안 제한 사양에 따른 전체적인 영양소의 부족과 목건초 에 비하여 볏짚의 총가소화영양소 함량이 낮은 결과로 사료된다. Table 6에서 나타낸바와 같이 고기의 물리적인 특성 및 일반성분을 살펴보면 목건초 및 볏짚 모두 비육기간이 증가할수록 고기의 질긴 정도를 파악할 수 있는 전단력의 수치가 낮아지는 것을 알 수가 있다. 이것은 거세 및 장기비육으로 고기속에 함유된 지방의 함량의 증가로 인한 근내지방도가 향상된 것으 로 사료된다.

본 시험에서는 공시한 한우는 4 개월령 전후 에 조기 거세한 것으로 비육기간이 연장될수록 전체적으로 전단력이 낮아지는 결과를 얻었다.

한편 비육기간이 증가할수록 근내지방도가 증가한다는 사실은 등심내부 조지방의 함량으 로도 알 수가 있다. 목건초 및 볏짚 모두 조지 방 함량이 유의적으로 증가 $(\mathrm{p}<0.05)$ 하는 것을 볼 수 있다.

\section{VI. 요 약}

본 시험을 수행하기 위해서 6개월령 거세한 우 64두를 공시하여 주구는 조사료원으로 목건 초와 볏짚 처리구를 배치하였으며, 세구는 출 하시기로 24 개월, 26 개월, 28 개월 및 30 개월 배 치하였다. 본 시험은 조사료원 및 출하시기별 발육 및 육질에 미치는 영향을 구명하기 위하 여 수행하였다. 발육 및 사료이용성은 목건초 급여구가 볏짚 급여구에 비하여 동일 출하월령 에서 $10 \sim 12 \%$ 정도 더 발육이 향상되었으며 $(\mathrm{p}<0.05)$, 배합사료 요구량에서도 목건초 급여 구가 볏짚 급여구에 비하여 $\mathrm{kg}$ 증체당이 향상 되는 결과를 얻었다. 또한 도체등급에서도 등 지방두께 및 배최장근단면적은 출하월령이 증 가할수록 증가하였으며, 근내지방도 역시 출하 월령이 증가할수록 증가하는 경향을 보였다.
따라서 한우 고급육을 생산하기 위해서는 볏짚 보다는 목건초 급여로 출하시기를 28 개월령 이 상 사육하는 것이 바람직한 것으로 사료된다.

\section{V. 인 용 문 헌}

1. 김강식. 1978. 한우의 사양 및 영양개선에 의한 육생산 능력증진에 관한 연구. 시험IV. 모우의 조기 육성 비육법과 관행 육성 비육법의 발육, 사료의 이용, 산육성 및 수익성의 비교. 한축지. 20(4):321.

2. 강태홍. 1979. 사료의 영양수준이 한우의 번식능 력 및 비육능력에 미치는 영향. 건국대학교 박사 학위 논문. 서울.

3. 백봉현, 김희열, 이병석, 신기준, 김영옥, 이근상. 1991. 육성비육 한우에 대한 완전사료 급여효과 에 관한 연구. 농사시험연구논문집 (축산편). 33 (1): 17 .

4. 백봉현, 신기준, 김용곤, 이근상, 김강식. 1987. 한우 육성비육시 체중별 육생산과 사료효율 및 적정 출하체중에 관한 연구. 농시연보(축산). 29 (1):6-13.

5. 백봉현, 이병석, 김용곤, 오학세, 이근상. 1992. 한우고급육 생산을 위한 사양관리 및 출하체중 에 관한 연구. 축시연보. pp.32-61.

6. 홍성구, 이병석, 강희설, 조성용, 백봉현, 정의수, 정천용. 1992. 한우의 비육시 급여 사료가 육질 에 미치는 영향. 축시연보. pp.69-98.

7. 홍성구, 이병석, 강희설, 정의수, 백봉현. 1994. 거세한우 육성비육시 담근먹이 급여가 발육 및 사료이용성에 미치는 영향. 농업과학논문집. 36 (2):491.

8. 홍성구, 백봉현, 강희설, 조원모. 1996. 거세한우 에 대한 제한급여 수준과 출하체중이 비육능력 및 육질에 미치는 효과. 한축지. 38(3):215-230.

9. 축산물등급판정소. 2001. 축산물등급판정세부기 준. 농림부 고시 제2001-38호.

10. Abdalla, H.O., D.G. Fox and M.L. Thonney. 1988. Compensatory gain by Holstein calves after underfeeding protein. J. Anim. Sci. 66:2687.

11. AOAC. 1990. Official Methods of Analysis (14th Ed.). Association of Official Analytical Chemsts, Washington, DC.

12. Berge, P. 1991. Long-term effects of feeding during calfhoods on ubsequents performance in 
beef cattle(a review) Livestock Prod. Sci. 28:179.

13. Boaz, T.G., Kirk, G. and C.L. Johnson. 1974. The effects of certain dietary regimes on growth pattern and performance of young Friesian bulls fattened for beef. J. Agric. Sci. 82:97.

14. Butterfield, R.M. and N.D.S, May. 1966. Muscle of the ox. University of Queensland Press, Brisbane, Australia.

15. Horton, G.M.J. 1978. The intake and digestibility of ammoniated cereal by cattle, Can. J. Anim. 58:471-478.

16. Martin, T.G., T.W. Perry, M.T. Mohler and F.H. Owens. 1978. Comparison of four levels of protein supplementation with and without oral diethylstilbestrol on daily gain, feed conversion and carcass traits of bulls. J. Anim. Sci. 48:1026.

17. O' Donovan, P.B. 1984. Compensatory gain on cattle and sheep. Nutr. Abstr. Rev. Ser. B 54:389.

18. Peterson, L.A., E.E. Hatfield and U.S. Garrigus. 1973. Influence of concentration of dietary energy on protein needs of growing-finishing cattle. J. Anim. Sci. 36:772.

19. SAS. 1997. SAS User's Guide : Statistics. SAS
Inst., Inc., Cary, NC.

20. Saubidet, C.L. and L.S. Verde. 1976. Relationship between live weight, age and dry-matter intake for beef cattle after different levels of food restriction. Anim. Proc. 22:61.

21. Skelley, G.C., R.L. Edwards, F.B. Wardlaw and A.K. Torrence. 1978. Selected high forage rations and their relationship to beef quality, fatty acids and amino acids. J. Anim. Sci. 47:1102.

22. Van Soest, P.J. 1982. Nutritional ecology of the ruminant. O and B Books, Inc., Corvallis, OR. p. 81-84.

23. Vanderwert, W., L.L. Berger, F.K. McKeith, R.D. Shanks and P.J. Bechtel. 1985. Influence of zeranol implants on growth carcass and palatability traits in bulls and late castrates. J. Anim. Sci. 61:537.

24. White, T.W. and W.L. Reynolds. 1969. Various sources and levels of roughage in steer rations. J. Anim. Sci. 29:705-710.

(접수일: 2009년 10월 5일, 수정일 1차: 2009년 10월 23일, 수정일 2차: 2009년 11월 5일, 게재확정일: 2009년 12월 7일) 